\title{
MOTIVATION AND PHYSICAL ACTIVITY TYPES: COMPARATIVE ANALYSIS
}

\author{
Viktorija Piščalkienè ${ }^{1}$, Milda Gintilienè ${ }^{1}$, Donatas Misiūnas ${ }^{1}$ Helen Kool${ }^{2}$, Jaana Siik ${ }^{2}$, \\ Petra Muraus ${ }^{3}$, Madara Juhna ${ }^{4}$, Inta Mikele ${ }^{4}$, Regitze Kristensen ${ }^{5}$ \\ ${ }^{1}$ Kaunas College / University of Applied Sciences, Lithuania, ${ }^{2}$ Lääne-Viru College, Estonia, \\ ${ }^{3}$ Southern-Savo Sports Federation, Finland, ${ }^{4}$ Riga 1st Medical college, Latvia, \\ ${ }^{5}$ UCL University College, Denmark
}

Key words: motivation, physical activity, project „Villages on Move Baltic".
Summary
The analysis was perfomed while participating and doing a research in a project "Villages on Move Bal- tic" (VOMB) 1.1.2016-31.12.2017 (Number 2016- 3715/001-001). The project's objective is to focus more Health Enhancing Physical Activity and joy of sports for rural citizen in participating regions. VOMB pro- ject is activating people to give ideas on how to pro- mote everyday physical activity and how to organise their leisure time in rural areas. The Project's partners have visited village events and have promoted healthy lifestyle. One of the goals is to motivate inhabitants in rural areas to have more physical activities and more joy of sports. Methods of the research: structured qu- estionnaire in written.
This article presents the results of internal and external motivation for most common physical activity types of citizens from participial countries in 6 months. In order to be physically active 6 indicators depended to external motivation and 12 to internal. Sample: there were 627 people from 5 European countries (Lithuania, Latvia, Estonia, Denmark, Finland). The research has shown that the most favorite types of physical activity are walking, riding a bike and running. However, the participants from Finland and Denmark were more motivated in all kinds of physical activities comparing to other participating countries.
Walking, gym, Nordic walking, swimming and yoga are the most popular forms of physical activities for the participants of urban areas. Gardening is more po- pular in rural areas. Participants from 18 to 44 years old are more physically active as they apply a variety of physical activities comparing to the participants in

45 to 59 age group. Almost all of the participants agree that health is a driving force of internal motivation for physical activity. To add more, almost all external factors are important to men and women, considering physical activity. Participants from rural areas more than respondents who live in settlements or cities agree on the idea that person's quality of life depends on personal efforts.

\section{Introduction}

Motivation is one of the most significant psychological concepts in many areas of life from every day needs, education and work to achieving personal goals $[1,17]$. In scientific articles it is discussed since the first goal setting study in the physical activity area was conducted [2]. In sports and physical activity, motivation plays an especially important part due to the fact that staying fit and active is not an obligation or a professional prerequisite, but rather a personal goal. The latest reviews have clearly shown that setting goals consistently contributes to improving the effectiveness of sports psychology, being effective at most sporting events and sports, and paying more attention to the key processes behind the setting of goals $[8,9]$.

How are individuals motivated to exercise, to be physically active? Self-control is an important concept for understanding motives. There are two categories of factors that influence selfcontrol: intrinsic motivators and extrinsic motivators [4]. Deci (1985) argue that intrinsic motivations are commonly those of competency, interest and enjoyment. Intrinsic motivation represents our internal drive toward behaviour, while extrinsic motivation includes factors such as rewards or punishment. The perception what best motivates individuals requires awareness of both the internal and external factors that regulate behaviour [11]. Both factors of motivation are important in order to achieve or maintain healthy active lifestyle. Practice or physical activity requires more internal motivation to 
strengthen the constant habit. There are many examples for internal motivation - better health, better personal skills and abilities, increased energy and reduced stress [13]. People who have successfully followed the physical activity plan are learning to shift their attention from long-term external stimuli to more positive internal experiences that occur in the short term. Ryan et al., (1997) examined exercise adherence with regard to intrinsic and extrinsic motivation. Although motivation to exercise includes both intrinsic and extrinsic elements. Intrinsic motivational sport maintains true value. Some people are physicaly active because they enjoy movement, while others may notice that each session has a personal challenge for them. Different activities even have quite specific mental effect - moving your body can strengthen your ideas. The hippocampus is that part of the brain that responds strongly to aerobic exercise. Well-controlled studies in children [3], adults [16] and the elderly [5] show that this brain structure is growing for people with higher levels of fitness. Since the hippocampus is a brain learning and memory center, this statement may partly explain the memory improvement while improving cardiovascular system. Researchers have shown that walking or cycling during training, but not before, helped to keep up the new foreign language vocabulary $[7,14,15]$. Regardless of the reason for the motivation to exercise, it must be from the inside of the person. Because person who are intrinsically motivated for physical activity they want to enjoy the positive feelings of success and the feeling that come from doing it well. Discussing about external motivation we can say that many people begin to exercise because they are motivated by external factors such as a desire to lose weight or wear smaller size [13].

Table 1. Socio-demographic characteristics of respondents $(\mathrm{N}=627)$

\begin{tabular}{|l|l|}
\begin{tabular}{|l|} 
Characteristics of \\
respondents
\end{tabular} & Percent (\%) \\
\hline GENDER & $54,8 \%$ \\
\hline Female & $45,2 \%$ \\
\hline Male & $78,8 \%$ \\
\hline AGE & $21,2 \%$ \\
\hline $18-44$ years & $53,8 \%$ \\
\hline $45-59$ years & $25,8 \%$ \\
\hline LIVING LOCATION & $20,4 \%$ \\
\hline City & \multicolumn{2}{|l|}{} \\
\hline Settlement & $22,5 \%$ \\
\hline Countryside & $24,7 \%$ \\
\hline COUNTRIES & $20,3 \%$ \\
\hline Lithuania (LT) & $21,1 \%$ \\
\hline Latvia (LV) & $11,5 \%$ \\
\hline Estonia (ES) &
\end{tabular}

Everyday promoting of any kind of physical activity is relevant to people of all different ages, abilities and levels of skills. This includes a multitude of useful benefits such as improving the health and well-being of individuals, provoiding joy of sports, contributing to the empowerment of individuals.

What motivates person to increase participation in more health enhancing physical activity? Enjoyable sports activities are effective way to improve health and well-being; it can relieve stress, increase fitness, improve physical and mental health, even prevent the development of chronic diseases [12]. Regular physical activity reduces risk of cardiovascular disease, thromboembolic stroke, hypertension, type 2 diabetes mellitus, osteoporosis, obesity, colon cancer, breast cancer, anxiety, and depression $[6,10]$.

Aim of article. The research was concerned with how external and internal motivations factors associated with physical activity might vary throughout the life in order to reveal methods of testing ideas in the project "Villages on Move Baltic".

\section{Material and methods}

Article was written while participating and doing a research in a project called "Villages on Move Baltic" (Erasmus+: Sport, Collaborative Partnerships, Grant Decision/Agreement No. 2016 - 3715/001-001). It was written by partners from Kauno kolegija / University of Applied Sciences (Lithuania), Lääne-Viru College (Estonia), Southern Savo Sports Federation (Finland), UCL University College Denmark. A research was also done in Latvia and it was done by academical staff from Riga 1 st Medical college.

Methods. Methods of the research: structured questionnaire in written. 6 indications depended to external motivation to be physically active and 12 to internal.

Data were processed using an SPSS program (Statistical Package for Social Sciences, version 21.0). Methods of statistical analysis: descriptive statistics, Student's T-Test, Anova test, Spearman Correlation Coefficient.

Participants. Sample: there were 627 people from $5 \mathrm{EU}$ countries (Lithuania, Latvia, Estonia, Denmark, Finland). Research was conducted from May of 2017 to June of 2018 year.

$54,8 \%$ participants of this survey were female and 45,2 $\%$ male. Participants were divided into 2 groups by the age: $78,8 \%$ depended to young age group (18-44 years), $21,2 \%$ - to middle age group.

$53,8 \%$ participants lived in the cities, $25,8 \%$ in the settlements and $20,4 \%$ in the villages. Among the people who participated, there were 22,5\% from Lithuania, 24,7 \% from Latvia, 20,3 \% from Estonia, 21,1 \% from Finland and 11,5 $\%$ from Denmark (Table 1). 
Results

Analysing the results of respondents from all 5 participial countries, it can be seen that the most favorite physical activity is walking (77\%). Biking is propagated by $43 \%$ of the participants (Fig. 1). As a form of physical activity running and going to the gym was considered by every third participant. Working in garden also requires physical strength, so $28 \%$ of participants were doing this activity. Moderately, every fifth participant $(21 \%)$ goes to the swimming pool. About 1 out of 10 enjoys visiting sport and social events that stimulate physical activity $(12 \%)$. Nordic walking and dancing show similar results. Least practised physical activities of the participants were yoga $(6 \%)$ and tennis $(3 \%)$.

The research has shown that one of the most popular forms of physical activity are walking, riding a bike and running (Fig.2). However, respondents presenting Finland and Denmark are prone to be more active in all kinds of physical activities. Walking can be described as a broad-based intensity physical activity. Respondents from Lithuania (60\%) and Estonia (68\%) were least to agree with the statement about walking, whereas almost 3/3 Finnish and Danish respondents were more likely to agree with this statement $(\mathrm{p}=0,011)$. Riding a bike is most popular in Denmark among the citizenry $(\mathrm{p}=0,000)$. Running, dancing and Nordic walking are also practiced mostly in Denmark and Finland $(p=0,000)$. At the same time, gardening is a popular form of physical activity in Estonia, Latvia and Lithuania $(p=0,000)$. Swimming is most popular among Estonian respondents $(p=0,000)$. Least acceptance was shown to physical activities like tennis and yoga, also, there were no measurable statistically significant differences considering the idea that people from one of the 5 respondential countries are more into those activities ( $\mathrm{p} \geq 0,05$ ).

Analysing forms of physical activity in accordance with residentiary it was clear that gardening is mostly practiced between people living in villages and other rural areas $(\mathrm{p}=0,000)$. However, other physical activity forms are more popular between people living in cities: walking $(p=0,16)$, gym $(p=0,05)$, Nordic walking $(\mathrm{p}=0,0006)$, swimming $(\mathrm{p}=0,021)$ and yoga $(\mathrm{p}=0,041)$.

Statistically significative differences were obtained between genders showing that some types of physical activity are related with the gender $(p \leq 0,05)$. Male research participants from Lithuania, Latvia, Estonia Denmark and Finland pointed out that their most popular forms of physical activity in last 6 months were: walking $(p=0,03)$, gym $(p=0,002)$, cycling $(p=0,006)$, running $(p=0,020)$, swimming $(\mathrm{p}=0,003)$ and gardening $(\mathrm{p}=0,002)$.

Statiscally significant differences were also seen showing the differences between two age groups in consideration of physical activity forms. Only in one case, people who were between 44-60 years old were more physicaly active while gardening ( $\mathrm{p}=0,000)$. In other cases, people between $18-44$ years old in last 6

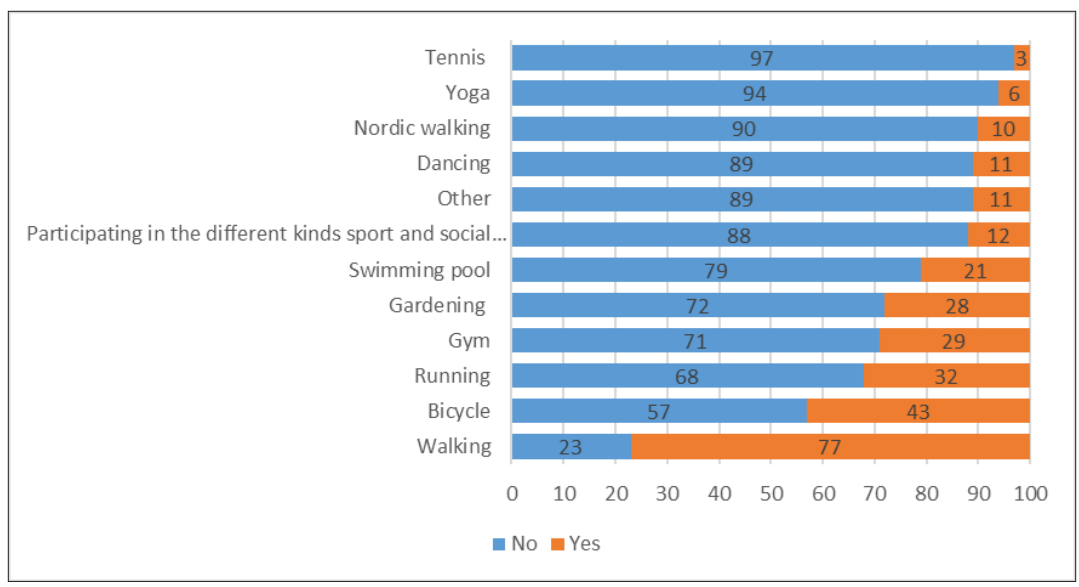

Fig. 1. Types of physical activities (all participants from Lithuania, Latvia, Estonia, Denmark, Finland)

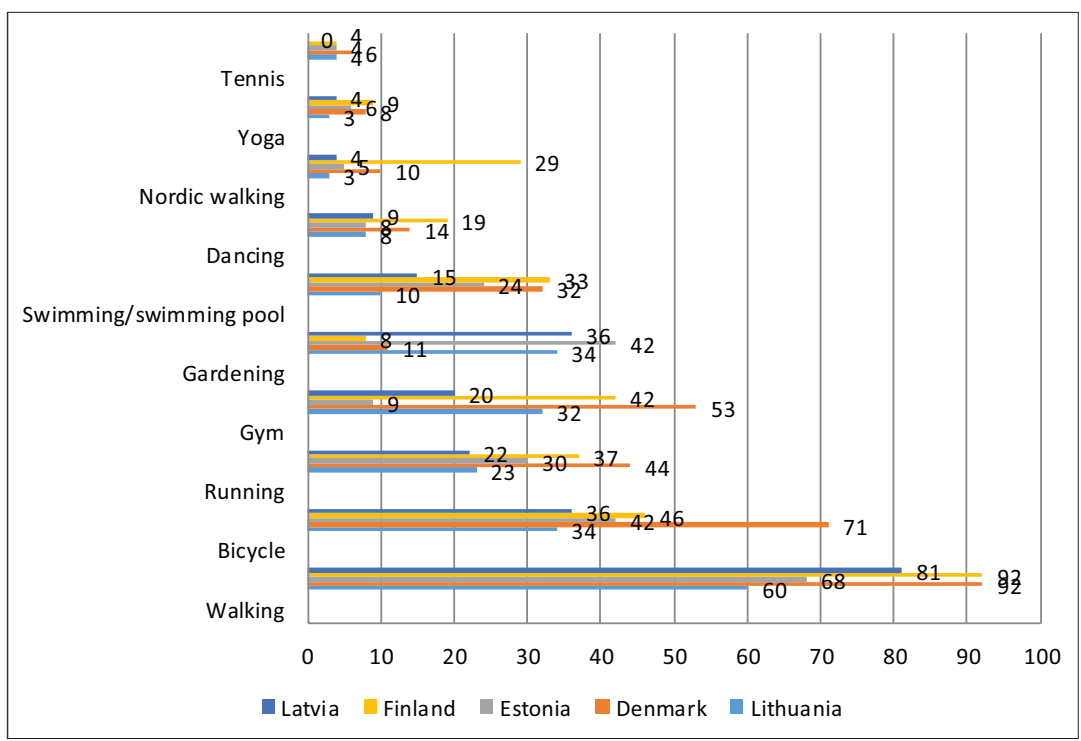

Fig. 2. Types of physical activities by the countries 
months had these types of physical activities: $\operatorname{gym}(\mathrm{p}=0,000)$, bicycle $(\mathrm{p}=0,002)$, walking $(\mathrm{p}=0,011)$, running $(\mathrm{p}=0,000)$, swiming $(\mathrm{p}=0,032)$, dancing $(\mathrm{p}=0,049)$.

It is clearly seen (Fig. 3) that showing a good example for your family is one of the most liked factors of respondents $(81 \%)$, which is considered to be an external motivational cause in regard to physical activity. Also, it is important for people to prove that not only others but also they are physically capable $(61 \%)$ and that others could see them in a good physical shape (62\%). Almost $2 / 3$ respondents thought that physical activity allows to establish social connection with new friends and to strengthen friendship while showing good examples to current friends. Media received least agreement as an external motivational factor for physical activity because only every other respondent thought that media was a good choice to form the image of physical activity in public.

A joyful fact was made that health is a very important internal motivational factor to physical activity and it was chosen by almost everyone in the research

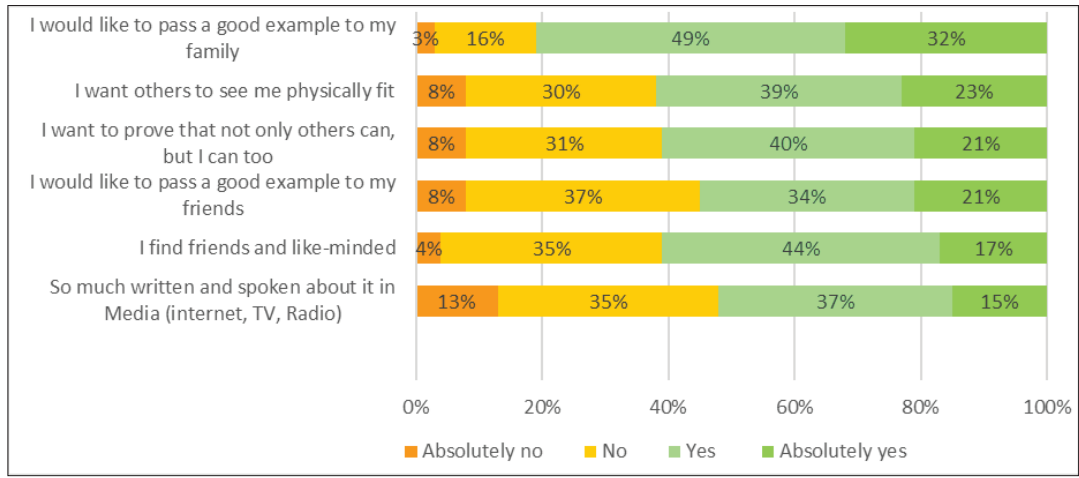

Fig. 3. External factors of motivation for physical activity (all participants from Lithuania, Latvia, Estonia, Denmark, Finland)

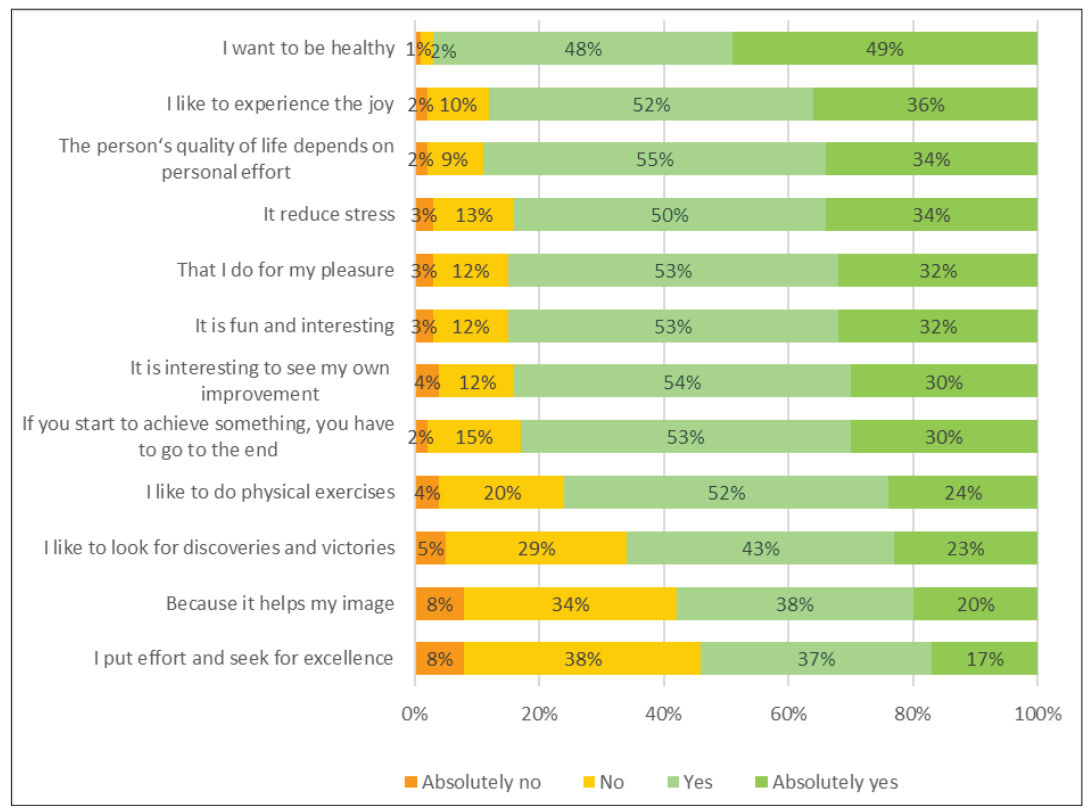

Fig. 4. Internal factors of motivation for physical activity (all participants from Lithuania, Latvia, Estonia, Denmark, Finland) (even $97 \%$ ). $3 / 3$ or a little less of respondents agreed, that physical activity allows to experience the joy, helps to reduce stress, it is pleasure, fun, and interesting to do it. On an average, every third respondent thought that they like discoveries, victories and it helps for personal image. Least favorite internal factor to be physically active was about putting the effort and seeking for excellence (Fig. 4).

Using a comparing test of two groups (Student's T-Test) was estimated that almost all external factors are equally important to motivation for physical activity for both men and women (Fig. 5). It is clear that women pay more attention to information about physical activity from media than men do $(\mathrm{p}=0.021)$. Agreement on other external motivational factors for physical activity was not so different for both male and female groups $(\mathrm{p} \geq 0,05)$.

A little more statistically important differences were found while analyzing men and women viewpoints about internal physical activity factors (Fig. 6). Men were more prone to think that person's quality of life depends on personal effort $(p=0,05)$. They also put more efforts and seek for excellence than women $(0,024)$ and like to look for discoveries and victories $(\mathrm{p}=0,000)$.

External physical activity motivational factors were a little different in different age groups (Fig. 7). Younger age group (until 44 years old) was more attentive about the image of physical activity made by media $(p=0,021)$. We can assume that it is because younger generation use more new technologies. Also, people that are in an age group until 44 years old are more inclined to prove that not only others but also they can reach goals associated with physical activity $(\mathrm{p}=0,001)$. For people until 44 years old it is also very important to show a good example about their physical activity for their family members $(\mathrm{p}=0,05)$.

Couple of differences were seen showing that younger age group (under 44 years old) had more positive attitude towards internal factors of motivation for physical activity (Fig. 8). People under 
44 years old more frequently agreed that they like to do physical activities $(\mathrm{p}=0,05)$ and they put more effort and seek excellence $(\mathrm{p}=0,000)$. Also, they think that physical activity is related to seeking for victories $(\mathrm{p}=0,000)$ and it is a part of creating an attractive looks $(\mathrm{p}=0,002)$.

In some cases there were statistically significant differences showing different outlooks on internal motivational factors to be physically active (Fig. 9). Comparing two different groups, a test was applied (Anova) and it showed that people from rural areas agree more that person's quality of life depends on personal efforts than respondents who live in settlements or cities $(p=0,015)$. Also people from villages think that if you start to achieve something, you have to go to the end $(\mathrm{p}=0,032)$. People from villages and other rural areas are more interested in physical activities because it is interesting for them to do it $(p=0,015)$. Evaluating external motivational factors for physical activity only one statistically significant discovery was found: people living in villages and rural areas physical activity associate with finding friends and like minded people more than people living in cities $(\mathrm{p}=0,005)$.

It indicated that people, who agreed more on statements about motivation for physical activity, in the last 6 months visited gym more often (correlation coefficient $0,240, p=0,000)$ and run more often (correlation coefficient $0,198, \mathrm{p}=0,000$ ).

However, in other cases big agreement on statements about motivation for physical activity is not related to being physicaly active in real life ( $\mathrm{p} \geq 0,05)$.

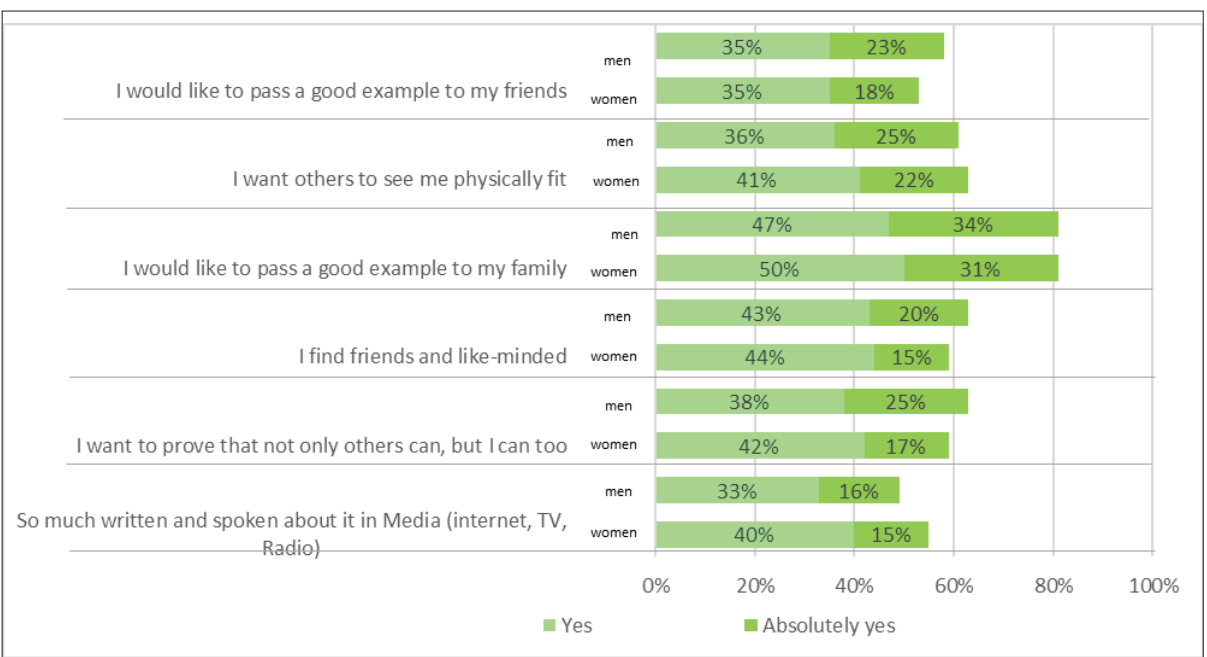

Fig. 5. External factors of motivation for physical activity by the gender (participants from Lithuania, Latvia, Estonia, Denmark, Finland)

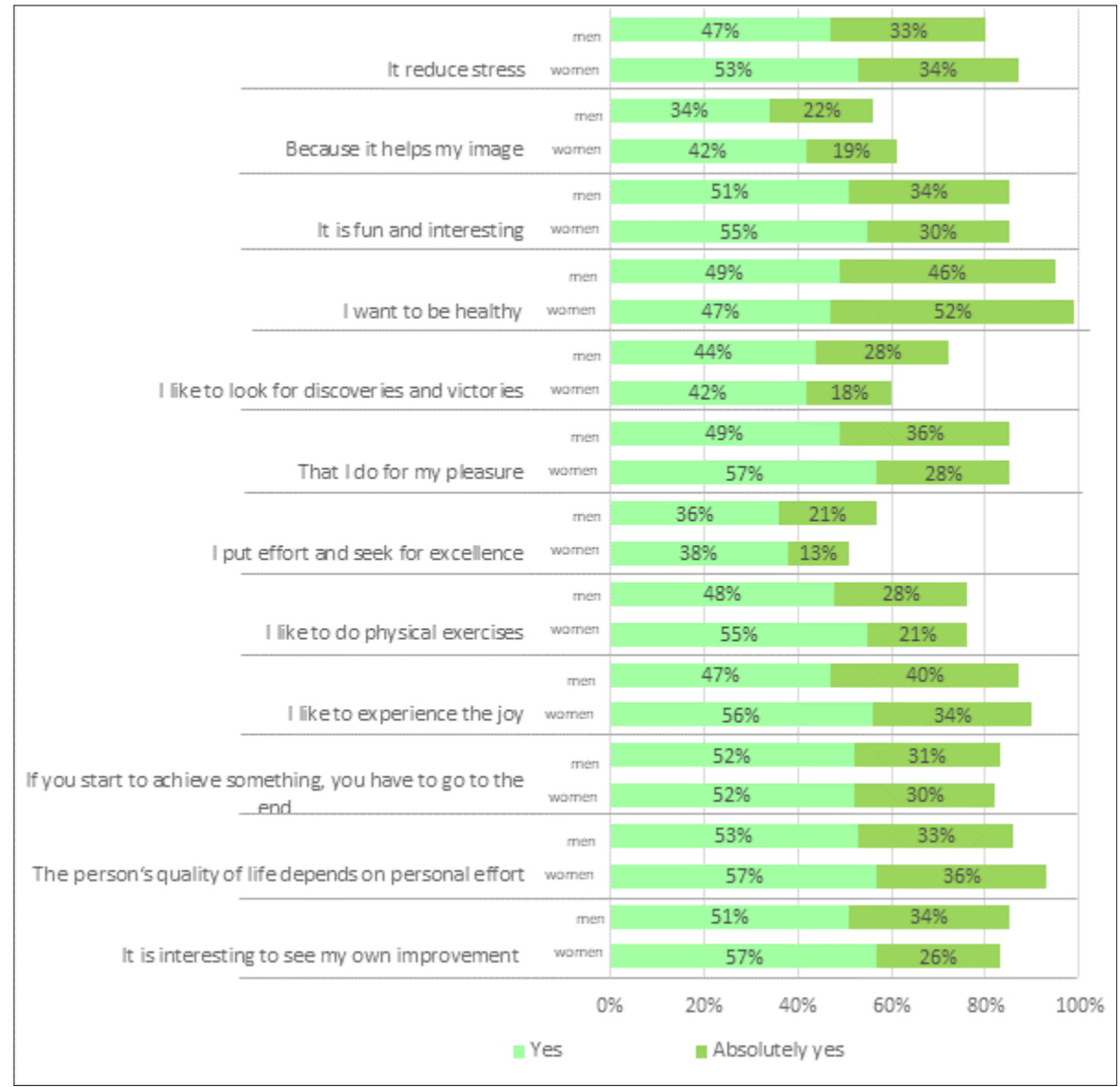

Fig. 6. Internal factors of motivation for physical activity by the gender (participants from Lithuania, Latvia, Estonia, Denmark, Finland). 


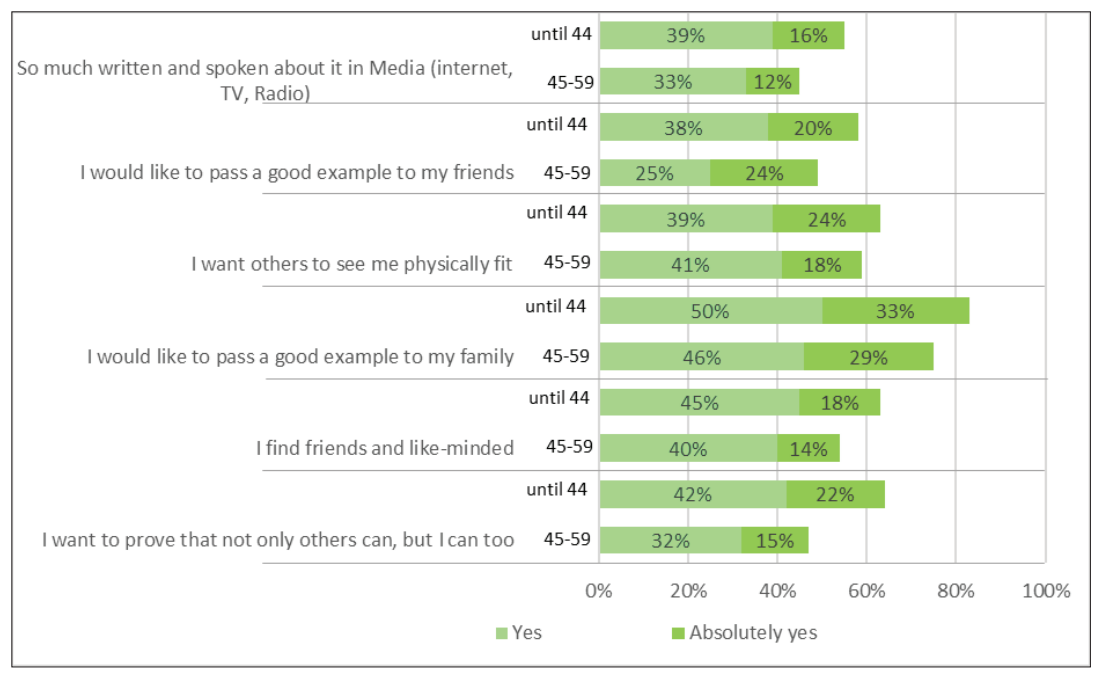

Fig. 7. External factors of motivation for physical activity by the age groups (participants from Lithuania, Latvia, Estonia, Denmark, Finland)

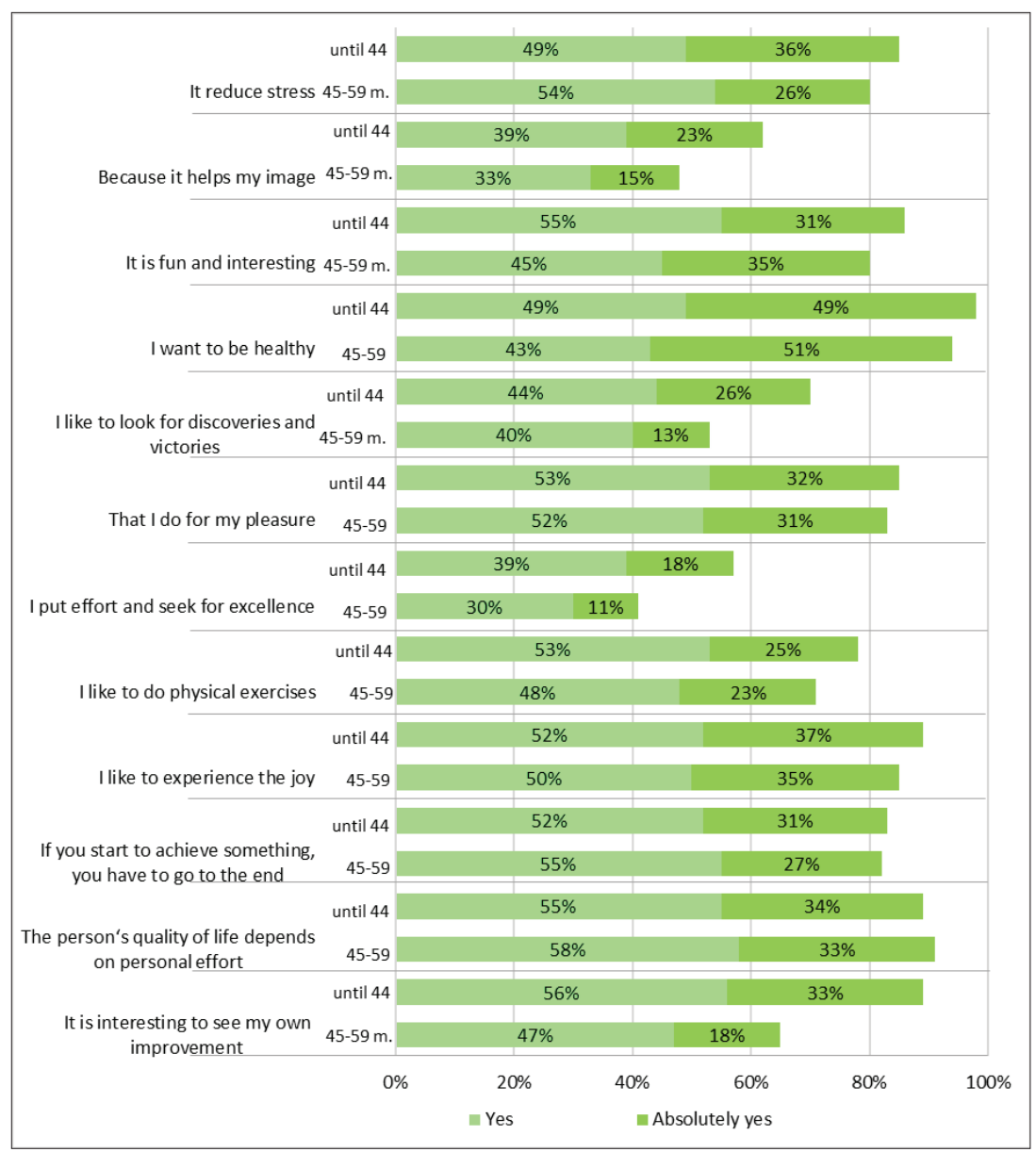

Fig. 8. Internal factors of motivation for physical activity by the age groups (participants from Lithuania, Latvia, Estonia, Denmark, Finland)
The study has shown participant country's different outlooks towards internal motivational factors. Most positive countries were Finland, Estonia, Latvia and Lithuania with respondents pointing out that physical activity relieves stress. The respondents from Denmark, on the other hand, agreed less with this statement $(p=0,000)$. Mostly going for self-growth were Lithuanian respondents, whereas Latvian and Estonian respondents had the lowest ratings in doing so $(\mathrm{p}=0,000)$. Lithuanian and Latvian respondents agreed more that the person's quality of life depends on personal effort and less agreed by respondents from Estonia and Denmark $(\mathrm{p}=0,000)$. Joy related with physical activity were more likely to experience Lithuanian respondents and Estonian and Latvian participants were least to experience it $(\mathrm{p}=0,000)$. People presenting Lithuania agreed more on a statement of „I put effort and seek for excellence" and statistically respondents from Latvia, Denmark and Finland were a little below $(p=0,000)$. Lithuanian citizens agreed the most that physical activity gives joy $(p=0,000)$. For the statement of looking and seeking for victories were more pasitive Lithuanian and Finnish respondents $(\mathrm{p}=0,000)$. Lithuanian respondents agreed the most with the statement „I want to be healthy“ ( $\mathrm{p}=0,000)$. For the statements „I would like to pass a good example to my family“ and ,I would like to pass a good example to my friends" Lithuanian, Latvian and Finnish respondents agreed the most $(\mathrm{p}=0,000)$. Also, Lithuanian, Latvian and Finnish respondents agreed the most with statements „I want others to see me physically fit“, „I find friends and like-minded“" and „I want to prove that not only others can, but I can too" $(\mathrm{p}=0,000)$. Same countries agreed about statement „So much written and spoken about it in Media" $(\mathrm{p}=0,000)$.

\section{Conclusions}

1. The research has shown that the most favorite forms of physical activities in Lithuania, Latvia, Estonia, Denmark 
and Finland are walking, riding a bike and running. However, the participants from Finland and Denmark were more active in all kind of physical activities comparing to other participating countries.

2. For the participants of urban areas, walking, gym, Nordic walking, swimming and yoga are the most popular forms of physical activities. Gardening is more popular in villages and rural areas. Participants from 18 to 44 years old are more physically active as they apply a variety of physical activities comparing to the participants of 45-59 age group.

3. Motivation is thought to be a combination of the drive within us to achieve our aims. Showing a good example to our family is one of the most common external factors mentioned by the participants. Least favorite external cause for motivation in regards to physical activity was media.

4. Almost all of the participants agree that health is a very important internal motivational factor for physical activity. To add more, almost all external factors are important to men and women, considering physical activity.

5. External physical activity motivational causes were a little bit different in different age groups. Younger citizens (under 44 years old) were more positive about internal and external factors of motivation for physical activity.

6. Participants from rural areas agree more on the idea that person's quality of life depends on personal efforts than respondents who live in settlements or cities.

7. Not in all cases strongly expressed motivation to be active physically is related to being physically active in real life. Denmark is a great example. Citizens of Denmark, that were participating in this research, had less positive outlook on motivational physical activities statements than Lithuanian and Latvian participants. Having said that, the research has shown that in real life people from Denmark and Finland are more active and they have a bigger variety of physical activities.

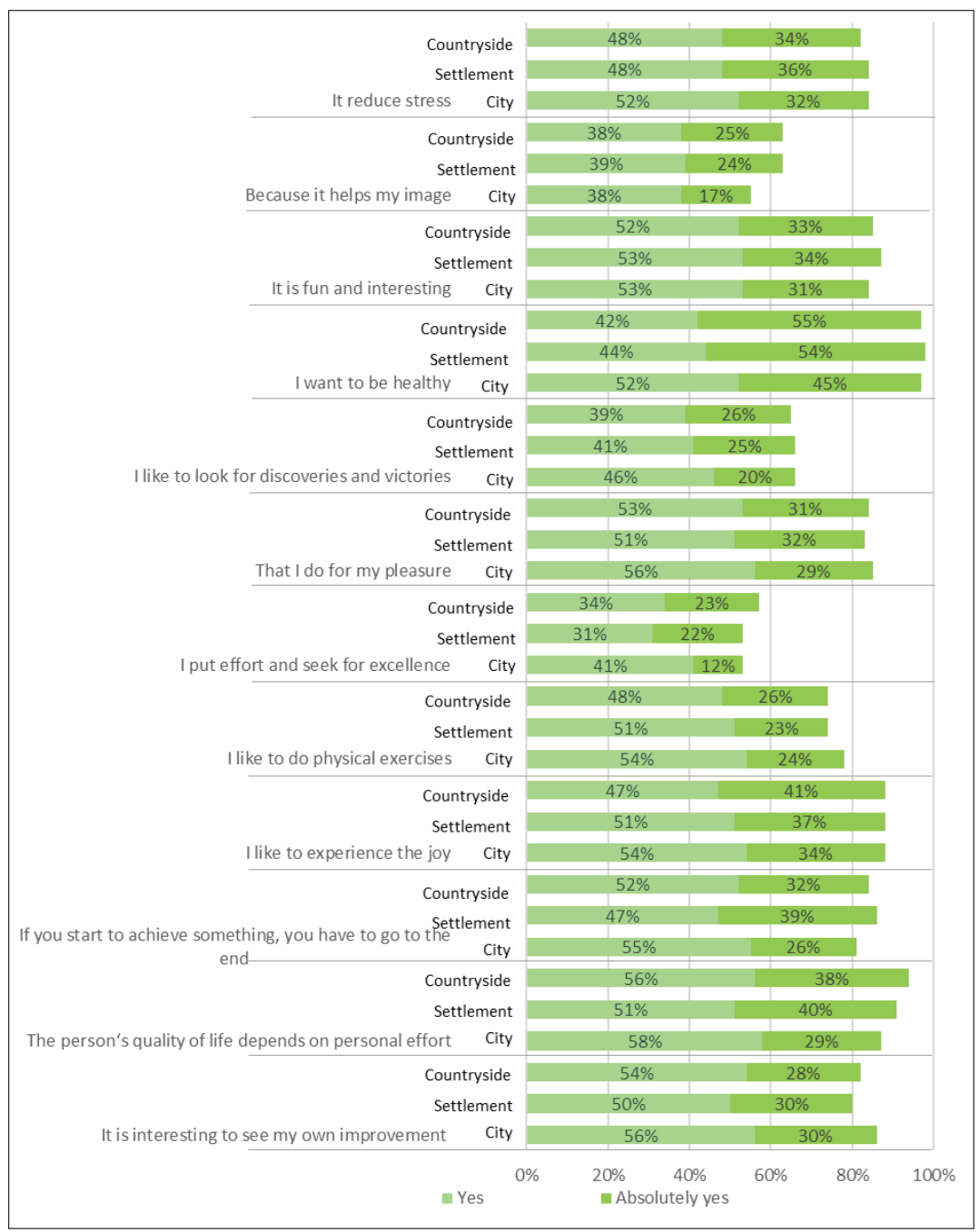

Fig. 9. Internal factors of motivation for physical activity by the living places (participants from Lithuania, Latvia, Estonia, Denmark, Finland)

\section{References}

1. Amabile T M. Motivational synergy: toward new conceptualizations of intrinsic and extrinsic motivation in the workplace. Human Resource Management Review 1993; 3: 185-201.

https://doi.org/10.1016/1053-4822(93)90012-S

2. Barnett M L. Effects of two methods of goal setting on learning a gross motor task. Research Quarterly 1977; 48:19-23.

https://doi.org/10.1080/10671315.1977.10762144

3. Chaddock L, Erickson K I, Prakash R S., Kim J S, Voss M W, Vanpatter M., Pontifex M B,Raine L B, Konkel A, Hillman C, Cohen N J, Kramer A F. A neuroimaging investigation of the association between aerobic fitness, hippocampal volume, and memory performance in preadolescent children. Brain Research 2010; 1358:172-183.

https://doi.org/10.1016/j.brainres.2010.08.049

4. Deci E L, Nezlek J, Sheinman L. Characteristics of the rewarder and intrinsic 
motivation of the rewardee. Journal of Personality and Social Psychology 1981; 40:1-10.

https://doi.org/10.1037/0022-3514.40.1.1

5. Erickson K I, Prakash R S, Voss M W, Chaddock L, Hu L, Morris K S, White S M, Wójcicki T R, McAuley E, Kramer A F. Aerobic fitness is associated with hippocampal volume in elderly humans. Hippocampus 2009; 19: 1030-1039. https://doi.org/10.1002/hipo.20547

6. Gavin J, Keough M, Abravanel M, Moudrakovski T, Mcbrearty M. Motivations for participation in physical activity across the lifespan. Int J Wellbeing 2014; 4(1):46-61. https://doi.org/10.5502/ijw.v4i1.3

7. Hotting K, Schickert N, Kaiser J, Roeder B, Schmidt-Kassow $M$. The effects of acute physical exercise on memory, peripheral BDNF, and cortisol in young adults. Neural Plasticity 2016; Article ID 6860573, 12 pages.

8. Klein H J, Wesson M J, Hollenbeck J R, Alge B J. Goal commitment and the goal setting process: Conceptual clarification and empirical synthesis. Journal of Applied Psychology 1999; 84: 885-896.

https://doi.org/10.1037/0021-9010.84.6.885

9. Locke E A, Latham G P. The application of goal setting to sports. Journal of Sport Psychology 1985; 7(3): 205-222. https://doi.org/10.1123/jsp.7.3.205

10. Nelson M E, Rejeski, W J, Blair S N, Duncan P W, Judge J O, King A C, Macera C, Sceppa C C, C. Physical activity and public health in older adults: recommendation from the American College of Sports Medicine and the American Heart Association. Medicine \& Science in Sports \& Exercise 2007; 39(8):1435-45.

https://doi.org/10.1249/mss.0b013e3180616aa2

11. Nicholls J G. Achievement motivation: Conceptions of ability, subjective experience, task choice, and performance. Psychological Review 1984; 91: 328-346.

https://doi.org/10.1037/0033-295X.91.3.328

12. Piščalkienė V, Gintilienė M, Misiūnas $D$, Rastenienė V, Mattila M, Muraus P, Kurtti M., Kool H., Siik J., Kristensen R., Selicka A. Methods of testing ideas in the project "Villages On Move Baltic": experiences from Baltic countries. Sveikatos mokslai/ Health Sciences 2018; 28 (2): 5-10.

https://doi.org/10.5200/sm-hs.2018.011

13. Ryan R M, Deci E L. Intrinsic and extrinsic motivations: classic definitions and new directions. Contemp. Educational Psychology 2000; 25 (1): 54-67.

https://doi.org/10.1006/ceps.1999.1020

14. Schmidt-Kassow M, Deusser M, Thiel C. et al. Physical exercise during encoding improves vocabulary learning in young female adults: a neuroendocrinological study. PLoS ONE 2013; $8(5)$.

https://doi.org/10.1371/journal.pone.0064172

15. Schmidt-Kassow M, Zink N, Mock J. et al. Treadmill walking during vocabulary encoding improves verbal long term memory. Behavioral and Brain Functions 2014; 10 (1): 24.

https://doi.org/10.1186/1744-9081-10-24

16. Thomas AG, Dennis A, Rawlings NB, Stagg CJ, Matthews L, Morris M, Kolind S, Foxley S, Jenkinson M, Nichols TE, Dawes H, Bandettini PA, Johansen-Berg H. Multi modal characterization of rapid anterior hippocampal volume increase associated with aerobic exercise. NeuroImage 2016; 131: 162-170.

https://doi.org/10.1016/j.neuroimage.2015.10.090

17. Zhang X M, Bartol K M. Linking empowering leadership and employee creativity: the influence of psychological empowerment, intrinsic motivation, and creative process engagement. The Academy of Management Journal 2010; 53: 107-128.

https://doi.org/10.5465/amj.2010.48037118

\section{MOTYVACIJA IR FIZINĖS VEIKLOS TIPAI: PALYGINAMOJI ANALIZE் \\ V.Piščalkiene, M.Gintilienė, D.Misiūnas, H.Kool, J.Siik, P.Muraus, M.Juhna, I.Miķele, R.Kristensen}

Raktažodžiai: motyvacija, fizinè veikla, projektas ,,Villages on Move Baltic (VOMB)“.

Santrauka

Analizė buvo atlikta dalyvaujant projekte ir vykdant tyrimą "Villages on Move Baltic" (Nr. 2016-3715/001-001). VOMB projektas aktyvina žmones pateikti idèjų apie kasdienio fizinio aktyvumo skatinimą, laisvalaikio kaimo vietovėse organizavimą. Projekto partneriai aplankè kaimo renginius ir skatino sveiką gyvenimo būdą. Vienas iš tikslų yra motyvuoti kaimo vietovių gyventojus turèti daugiau fizinès veiklos ir daugiau patirti džiaugsmo sportuojant. Tyrimo metodai: struktūrinis klausimynas raštu.

Šiame straipsnyje pristatomi 6 mènesių projekte dalyvaujančių šalių gyventojų labiausiai paplitusių fizinio aktyvumo tipų vidinès ir išorinès motyvacijos rezultatai. Siekiant būti fiziškai aktyviems, 6 rodikliai priklausė nuo išorinès motyvacijos, o 12 - nuo vidinès. Tyrimo imtis: tyrime dalyavavo 627 asmenys iš 5 Europos šalių (Lietuva, Latvija, Estija, Danija, Suomija). Tyrimai parodè, kad labiausiai mėgstamos fizinės veiklos rūšys yra vaikščiojimas, važiavimas dviračiu ir bejgiojimas. Suomijos ir Danijos tiriamieji buvo labiau motyvuoti visų rūšių fizinėse veiklose lyginant su kitomis dalyvaujančiomis šalimis.

Vaikščiojimas, užsièmimai treniruoklių salèje, šiaurietiškas èjimas, plaukimas ir joga yra populiariausios miesto gyventojų fizinio aktyvumo formos. Sodininkystė yra populiaresnė kaimo vietovèse. Vertinant pagal amžių, 18 - 44 metų asmenys yra labiau fiziškai aktyvūs ir taiko ịvairias fizines veiklas, nei 45-55 metų amžiaus tiriamieji. Beveik visi dalyviai sutinka, kad sveikata yra fizinés veiklos motyvacijos varomoji jèga. Dauguma išorinių veiksnių yra svarbūs vyrams ir moterims. Kaimo vietovių dalyviai, daugiau nei gyvenantys miestuose, teigia, kad asmens gyvenimo kokybė priklauso nuo asmeninių pastangų.

Adresas susirašinėti: viktorija.piscalkiene@go.kauko.lt

Gauta 2018-10-31 